\title{
Recovery of Sb and Fe from Sb-bearing Slags through a Reduction Roasting Process with Low Density Polyethylene
}

\author{
Cheng $\mathrm{TAN}^{1)}$ Hongjuan $\mathrm{LI}^{2{ }^{2)}}{ }^{3}$ Jinyan $\mathrm{LI}^{3)}$ and Lei $\mathrm{LI}^{1)}$ \\ 1) State Key Laboratory of Complex Non-ferrous Metal Resources Clean Utilization, Engineering Research Center of Metal- \\ lurgical Energy Conservation and Emission Reduction of Ministry of Education, Faculty of Metallurgical and Energy Engineer- \\ ing, Kunming University of Science and Technology, Kunming, 650093 P. R. China. \\ 2) Quality Development Institute, Kunming University of Science and Technology, Kunming, 650093 P. R. China. \\ 3) Department of Metallurgy and Raw Materials, China Metallurgical Industry Planning and Research Institute, Beijing, 100711 \\ P. R. China.
}

(Received on January 23, 2019; accepted on May 21, 2019)

\begin{abstract}
A novel method for treating the Sb-bearing slag using LDPE as a reductant under $\mathrm{N}_{2}$ atmosphere is proposed. The $\mathrm{H}_{2}, \mathrm{CH}_{4}$ and $\mathrm{C}_{2}\left(\mathrm{C}_{2} \mathrm{H}_{6}, \mathrm{C}_{2} \mathrm{H}_{4}, \mathrm{C}_{2} \mathrm{H}_{2}\right)$ are released quickly during the LDPE pyrolysis process, and some of them have escaped off the roasting system before the reaction with the Sb-bearing slag. The $\mathrm{Sb}, \mathrm{Pb}$ and $\mathrm{Fe}$ phases in the original Sb-bearing slag could be selectively reduced to $\mathrm{Sb}_{4} \mathrm{O}_{6}, \mathrm{~Pb}$ and $\mathrm{Fe}_{3} \mathrm{O}_{4}$ respectively by the pyrolysis gas at roasting temperature of $1000^{\circ} \mathrm{C}$ and LDPE amount of $25 \mathrm{wt} \%$. The $\mathrm{Sb}_{4} \mathrm{O}_{6}$ could be separated and recovered effectively with the volatilization rate of $93.51 \%$ accompanying the $\mathrm{Pb}$ volatilization rate was only around $0.68 \%$ and the $\mathrm{Fe}$ phase was almost transformed into $\mathrm{Fe}_{3} \mathrm{O}_{4}$ retaining in the residue. Then the $\mathrm{Fe}_{3} \mathrm{O}_{4}$ can be separated and collected from the roasted residues using magnetic separation process.
\end{abstract}

KEY WORDS: Sb-bearing slag; LDPE; selective reduction; Sb separation; Fe recovery.

\section{Introduction}

The $\mathrm{Sb}$ has a variety of industrial application, especially for manufacture of flame retardant, sliding bearing and welding flux. ${ }^{1-3)}$ Due to the depletion of antimony primary ore resource, recovery of it from secondary resources has gained attention, such as from Sb-bearing slags, As-Sb dust and $\mathrm{Sb}$ alloy scraps. ${ }^{4-6)}$ The corresponding processing methods existed mainly consists of pyrometallurgical and hydrometallurgical processes, and the separation of $\mathrm{Sb}$ from As and/or $\mathrm{Pb}$ compounds is the key problem. A high separation rate of $\mathrm{As}$ from $\mathrm{Sb}$ phases could be obtained in the previous researches. For the hydrometallurgy process, the As was selectively leached into solution and separated from $\mathrm{Sb}$ phases using alkali, ${ }^{7,8)}$ hot water, ${ }^{9}$ or by chlorination. ${ }^{10)}$ Meanwhile, the $\mathrm{Sb}$ was transformed into insoluble matter and separated by filtration. The arsenic removal rate also reached above 90 mass \% through a selective oxidation roasting process with $\mathrm{CuO},{ }^{11)} \mathrm{MnO}_{2}{ }^{6)}$ and $\mathrm{Fe}_{2} \mathrm{O}_{3}$, ${ }^{5)}$ and the $\mathrm{Sb}$ was oxidized to $\mathrm{Sb}_{2} \mathrm{O}_{4}$ and remained in the roasted residue. The traditional treatment of $\mathrm{Pb}-\mathrm{Sb}$ alloy for separating $\mathrm{Sb}$ is blowing smelting in reverberatory furnace, in which the $\mathrm{Sb}$ volatilizes in the form of $\mathrm{Sb}_{2} \mathrm{O}_{3}$. There exists many shortcomings in this conventional method, such as high energy consumption and low separation efficiency between

\footnotetext{
* Corresponding author: E-mail: 252972286@qq.com

DOI: https://doi.org/10.2355/isijinternational.ISIJINT-2019-055
}

$\mathrm{Sb}$ and $\mathrm{Pb}^{12)}$ Many researchers developed some other methods to resolve this problem, such as vacuum distillation, reducing-matting smelting and leaching technology in chloride system. ${ }^{13)}$ However, there still exist some problems for them being applied in the industry containing high power consumption and expensive production. Based on the difference in vapor pressure of substances in Sb-bearing slags, Qiu Keqiang and Zhang Rongliang found that the $\mathrm{Sb}_{2} \mathrm{O}_{3}$ could be separated from $\mathrm{PbO}$ and $\mathrm{SnO}_{2}$ through vacuum evaporation process at temperature of $893 \mathrm{~K}$ and pressure of $250 \mathrm{~Pa}$. However, the results showed that the evaporation rate of $\mathrm{Sb}$ was only $59.15 \% .^{14)}$ As an intermediate produced from pyrometallurgy of jamesonite, the Sb-rich oxidizing slag is mainly composed of $\mathrm{Sb}$ and $\mathrm{Pb}$ oxides, as well as $\mathrm{Sn}, \mathrm{Fe}$, and As etc. This Sb-rich oxidizing slag is now mainly processed by smelting reduction method. However, it increases energy consumption and decreases the recovery rates of $\mathrm{Sb}$ and $\mathrm{Pb}$ obviously due to repeated smelting. Meanwhile, an ultrasound-assisted $\mathrm{HCl}-\mathrm{NaCl}$ leaching method was employed to recover $\mathrm{Pb}$ and $\mathrm{Sb}$ from this Sb-rich oxidizing slag in the research of Rong Liang Zhang et al., and they found that increasing ultrasonic power could augment the leaching rate or accelerate the procedure. However, the recovery rates of $\mathrm{Sb}$ and $\mathrm{Pb}$ were also relatively low in this process, which were around $85 \%$ and $75 \%$ respectively. ${ }^{15)}$

Plastics are a standard group of synthetic or natural materials with carbon and hydrogen as major element. They 
are highly durable, strong, elastic and cheap to produce, which make them an ideal choice for packaging and storage applications. ${ }^{16)}$ The global production of plastics keeps increasing and so does the waste generation. These plastics are abundantly present in municipal solid waste. Plastic recovery can be divided into material recycling and energy recovery, which depends on the plastics types, segregation from other materials, and cost aspects of process. Thermal degradation of plastics is of increasing concern for recycling them in the form of energy through the conversion to gas, liquid and solid products. ${ }^{17}$ Low and high density polyethylene (LDPE \& HDPE) and polypropylene (PP) are the three major kinds. ${ }^{18)}$ Due to the lack of management from the governing organizations, the plastic waste goes to dumping sites along with other waste materials. ${ }^{19)}$ The disposal of them is currently a challenge because the dumping of them in landfills is no longer permitted in some countries. Most of them are recycled or recovered, and the gasification or pyrolysis, seems to be the future for them treatment. ${ }^{20,21)}$ The composition of pyrolysis products is widely different due to the thermal behavior and reactivity of these plastics, which are mainly determined by the virgin materials, the reactor type, or the applied process parameters. ${ }^{22)}$

In the pyrolysis of LDPE type plastic wastes, around of $30.9 \%$ gas was yielded at $600^{\circ} \mathrm{C}$, and $\mathrm{H}_{2}, \mathrm{CH}_{4}$ and $\mathrm{C}_{2}-\mathrm{C}_{4}$ hydrocarbons made for $58.3 \%, 20.3 \%$ and $21.4 \%$ respectively. ${ }^{23)}$ There is a dramatic increase in gas yield with increasing temperature. At pyrolysis temperature of $740^{\circ} \mathrm{C}$, there was an almost complete conversion of the LDPE to gas. ${ }^{24)}$ The products of the LDPE pyrolysis can be used as reductant, but little attention has been given to it. A novel method for treating Sb-bearing slag using LDPE under $\mathrm{N}_{2}$ atmosphere is proposed in this paper. Here, the "Sb" phases are reduced and then volatilized in the form of $\mathrm{Sb}_{4} \mathrm{O}_{6}$. Meanwhile, the "Fe" and " $\mathrm{Pb}$ " phases in the slag are reduced $\mathrm{Fe}_{3} \mathrm{O}_{4}$ and metallic $\mathrm{Pb}$ respectively and remain in the residue, and they can be separated and recovered using a general magnetic separation method.

\section{Materials and Methods}

\subsection{Experimental Materials and Analyses}

The Sb-bearing slag used in this study was supplied by a plant for treating high As-Sb dust using pyrometallurgical processes locating in Yunnan province of China. The LDPE was obtained from Shengwang Ltd. in China. Nitrogen (purity of 99.99\%) was procured from local supplier.

The composition of the slag was characterized by chemical analysis, and the result is presented in Table 1. It shows that the slag mainly comprises 42.04 wt. $\%$ Sb, 21.31 wt.\% $\mathrm{Fe}$ and 6.24 wt.\% $\mathrm{Pb}$, which are all valuable to be recovered. The "Others" in Table 1 are mainly composed of "O", "Ca", and "Si", etc. X-ray diffraction (XRD, Rigaku, TTR-III) study with $2 \theta$ varying from 10 to $90^{\circ}$ using $\mathrm{Cu}$ Ka radiation $(\lambda=1.54 \AA$ at $40 \mathrm{kV}$ and $200 \mathrm{~mA})$ at a scan-

Table 1. Chemical composition of the Sb-bearing slag.

\begin{tabular}{ccccccc}
\hline Components & $\mathrm{Sb}$ & $\mathrm{Fe}$ & $\mathrm{Pb}$ & $\mathrm{Bi}$ & $\mathrm{Cu}$ & Others \\
\hline $\mathrm{Wt}(\%)$ & 42.04 & 21.31 & 6.24 & 0.57 & 0.22 & 29.12 \\
\hline
\end{tabular}

ning rate of $10^{\circ} / \mathrm{min}$ was carried out to determine the phases in the slag. The XRD spectrum in Fig. 1 indicates that the slag mainly comprises $\mathrm{Sb}_{2} \mathrm{O}_{4}, \mathrm{Sb}_{6} \mathrm{O}_{13}, \mathrm{~Pb}_{2} \mathrm{Sb}_{2} \mathrm{O}_{7}, \mathrm{PbSb}_{2} \mathrm{O}_{6}$, $\mathrm{Fe}_{2} \mathrm{O}_{3}$ and $\mathrm{FeSbO}_{4}$. An electron probe microscopic analysis (EPMA-JAX8230, JEOL, Japan) was carried out to detect the elemental distribution in various phases of the slag. Figure 2 and Table 2 show the focal points of analysis in the raw material. It can be seen that the major phases present include $\mathrm{Fe}_{2} \mathrm{O}_{3}$, and coexistent phases of $\mathrm{Pb}-\mathrm{Sb}-\mathrm{O}, \mathrm{Fe}-\mathrm{Sb}-\mathrm{O}$ and $\mathrm{Pb}-\mathrm{Sb}-\mathrm{Fe}-\mathrm{O}$, which is consistent with the XRD result in Fig. 1.

\subsection{Experimental Methods}

The experiment was carried out in a tube furnace (GSL1500X, Hefei Kejing Materials Technology Co. Ltd., China), and the roasting temperature was measured by a $\mathrm{Pt}-\mathrm{Rh}$ thermocouple and controlled by a KSY Intelligent Temperature Controller (accuracy $\pm 1 \mathrm{~K}$ ). The LDPE addition amount was given based on the quality ratio of it to the slag in all the tests.

The slag was firstly grounded and sieved to yield a particle size below $74 \mu \mathrm{m}$, and then mixed thoroughly with a given amount of LDPE at a particle size of $1-3 \mathrm{~mm}$. For each experiment, $6 \mathrm{~g}$ of samples (mixture of the dust and LDPE) were used. The $\mathrm{N}_{2}(150 \mathrm{ml} / \mathrm{min})$ was sent into the furnace during the preheating and experimental process. The reactor containing the sample was weighed and placed in the constant temperature zone of the furnace when the furnace temperature reached a desired value and then held for a preset time. After a required time, the sample was cooled in $\mathrm{N}_{2}$ atmosphere, weighed when the temperature reached room temperature, and prepared for analysis. The gases evolved throughout were collected in a Teflon gas sample bag and analyzed off-line by Agilent 7890A GC. The volatilization rates, $\alpha$ and $\beta$, for antimony and lead respectively, were calculated through Eqs. (1) and (2).

$$
\alpha=\left(1-\frac{m \times w_{A}}{m_{R} \times w_{A R}}\right) \times 100 \%
$$

$$
\beta=\left(1-\frac{m \times w_{P}}{m_{R} \times w_{P R}}\right) \times 100 \%
$$

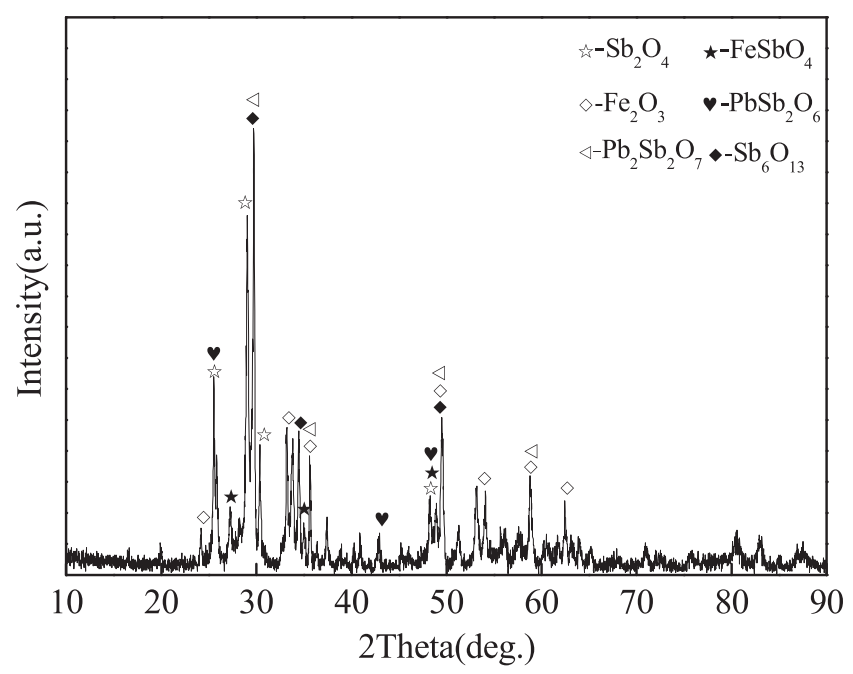

Fig. 1. X-ray diffraction pattern of the Sb-bearing slag. 
where $m_{R}$ and $m$ stand for total mass of the raw materials and roasted residues, respectively; $\mathrm{w}_{\mathrm{AR}}$ and $\mathrm{w}_{\mathrm{PR}}$ are mass contents of $\mathrm{Sb}$ and $\mathrm{Pb}$ in the raw materials, and $\mathrm{w}_{\mathrm{A}}$ and $\mathrm{W}_{\mathrm{P}}$ are mass contents of $\mathrm{Sb}$ and $\mathrm{Pb}$ in the roasted residues, respectively.

\section{Thermodynamic Analysis}

\subsection{LDPE Pyrolysis}

It is well-known that the polymer degradation in LDPE by thermal cracking is carried out according with a radical chain mechanism, which proceeds via a random chain scission to form primary radicals. This process includes chain initiation (a), chain reaction (b, c, d, e), and chain termination $(\mathrm{f})^{25)}$ as shown in Fig. 3. Meanwhile, the alkanes and alkenes can further decompose into char and hydrogen

Table 2. Elemental analysis of different points corresponding in Fig. 2 (mole\%).

\begin{tabular}{ccccc}
\hline Elements/Mole fraction & $\mathrm{O}$ & $\mathrm{Fe}$ & $\mathrm{Sb}$ & $\mathrm{Pb}$ \\
\hline $\mathrm{pt} 1$ & 41.45 & 58.55 & & \\
$\mathrm{pt} 2$ & 49.66 & 19.10 & 20.04 & 11.20 \\
$\mathrm{pt} 3$ & 56.90 & & 26.55 & 16.55 \\
$\mathrm{pt} 4$ & 61.74 & 22.62 & 15.64 & \\
\hline
\end{tabular}

(g). ${ }^{26)}$ Pyrolysis temperature is one of the most important operating parameters affecting the products composition. Higher temperature enhances bond breaking and favors the production of smaller molecules. As shown in Fig. 4, the mole fraction of $\mathrm{C}_{2}\left(\mathrm{C}_{2} \mathrm{H}_{6}, \mathrm{C}_{2} \mathrm{H}_{4}, \mathrm{C}_{2} \mathrm{H}_{2}\right)$ decreases while the $\mathrm{C}_{1}\left(\mathrm{CH}_{4}\right)$ mole fraction increases with temperature before $1000^{\circ} \mathrm{C}$. Then the $\mathrm{C}_{1}\left(\mathrm{CH}_{4}\right)$ mole fraction decrease with

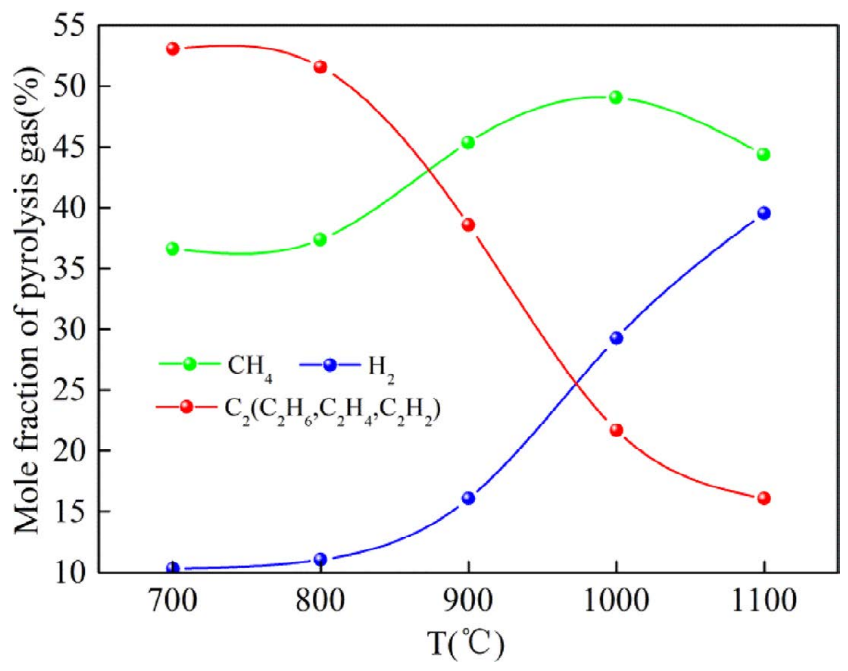

Fig. 4. Mole fraction changes of pyrolysis gas with temperature. (Online version in color.)
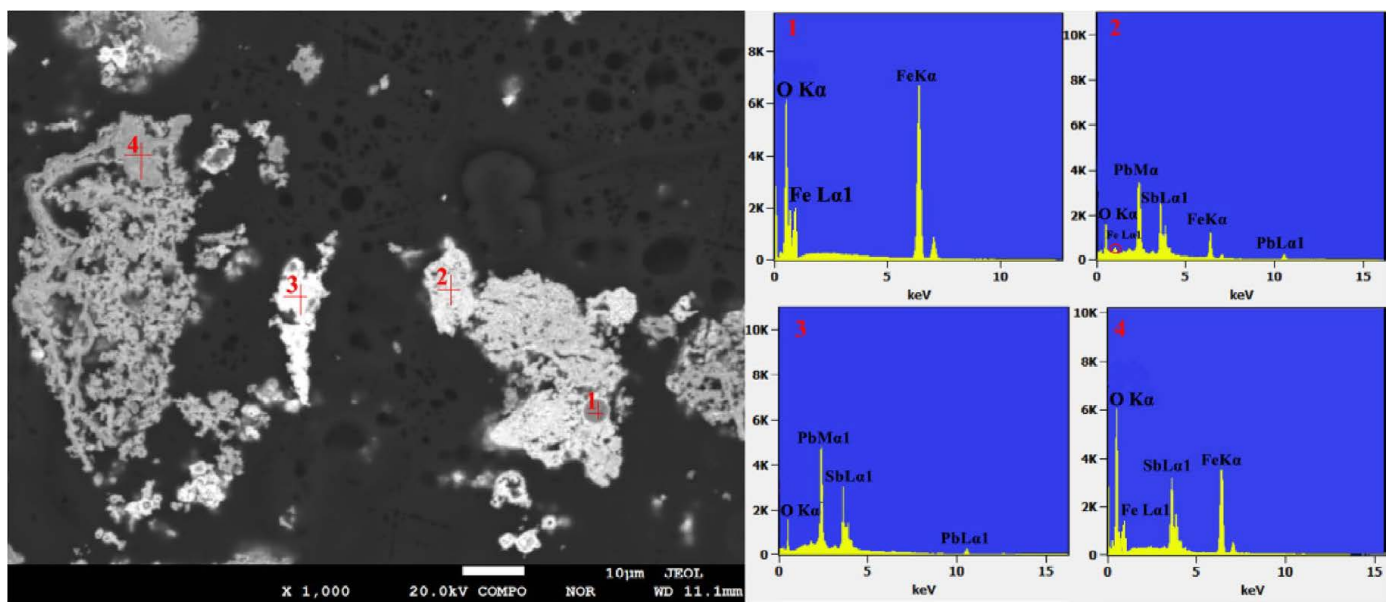

Fig. 2. EPMA-EDS analysis of the Sb-bearing slag. (Online version in color.)

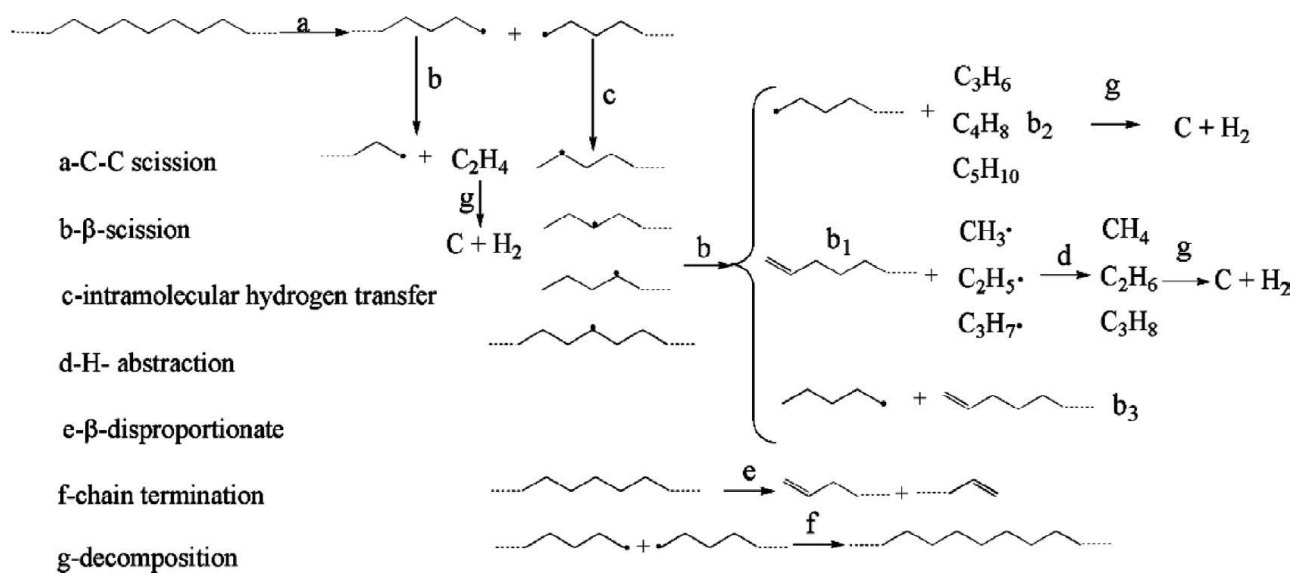

Fig. 3. Thermal degradation mechanism of LDPE. 
temperature being higher than $1000^{\circ} \mathrm{C}$ due to it decomposition to $\mathrm{H}_{2}$.

\subsection{Reactions between the LDPE and Sb-bearing Slag}

The LDPE is assumed to be thermal decomposed firstly and then reacted with the Sb-bearing slag. Selecting the pyrolysis products of LDPE in Fig. 4 and components existed in the Sb-bearing slag (Fig. 1) as reactant precursors, the FactPS, FToxid and FTOxCN databases of FactSage 7.0 were used to calculate the reaction equilibrium between the LDPE and Sb-bearing slag by minimizing Gibbs free energy under isothermal, isobaric and fixed-mole conditions. The phases of $\mathrm{O}_{2}(\mathrm{~g}), \mathrm{Pb}(\mathrm{s}), \mathrm{PbO}(\mathrm{s}), \mathrm{Sb}_{2} \mathrm{O}_{4}(\mathrm{~s}), \mathrm{Sb}_{4} \mathrm{O}_{6}(\mathrm{~g}), \mathrm{Sb}(\mathrm{s})$, $\mathrm{Fe}_{2} \mathrm{O}_{3}(\mathrm{~s}), \mathrm{Fe}_{3} \mathrm{O}_{4}(\mathrm{~s}), \mathrm{FeO}(\mathrm{s})$, and $\mathrm{Fe}(\mathrm{s})$ were assumed to be present in the roasted products, and the other generated phases with low contents or outside the scope of this work are not shown in the output results (Fig. 5) due to their little contents. Figure 5 shows that with the increase of pyrolysis gas amount from 0 to 0.5 , the $\mathrm{Sb}_{2} \mathrm{O}_{4}$ (s) amount decreases while $\mathrm{Sb}_{4} \mathrm{O}_{6}(\mathrm{~g})$ and $\mathrm{Sb}(\mathrm{s})$ amounts increase attributed to the reduction between pyrolysis gas and $\mathrm{Sb}_{2} \mathrm{O}_{4}$ (s), and the $\mathrm{Sb}_{4} \mathrm{O}_{6}(\mathrm{~g})$ is the main reduction product at pyrolysis gas amount of 0.5 and $900-1100^{\circ} \mathrm{C}$. As the pyrolysis gas amount increases over 0.5 , the $\mathrm{Sb}_{4} \mathrm{O}_{6}(\mathrm{~g})$ will be reduced into $\mathrm{Sb}$ and the $\mathrm{Sb}$ amount increases obviously. In addition, the $\mathrm{Pb}$-containing phases are almost reduced to $\mathrm{Pb}(\mathrm{s})$ with the pyrolysis gas amount of 0.5 and 0.75 at temperature of $700-900^{\circ} \mathrm{C}$ and $1000-1100^{\circ} \mathrm{C}$ respectively, and the iron phases are almost transformed to $\mathrm{Fe}_{3} \mathrm{O}_{4}$ (s) with the pyrolysis gas amount of 0.5 at temperature of $700-1000^{\circ} \mathrm{C}$. The $\mathrm{Sb}$ phases can be separated effectively from the slag in the form of $\mathrm{Sb}_{4} \mathrm{O}_{6}(\mathrm{~g})$ at temperature of $900^{\circ} \mathrm{C}$ and pyrolysis gas amount of 0.5 from the point of view of therm odynamics, while the $\mathrm{Fe}$ and $\mathrm{Pb}$ phases are transformed to $\mathrm{Fe}_{3} \mathrm{O}_{4}(\mathrm{~s})$ and $\mathrm{Pb}(\mathrm{s})$ respectively which could be separated and recovered by a general magnetic separation process.
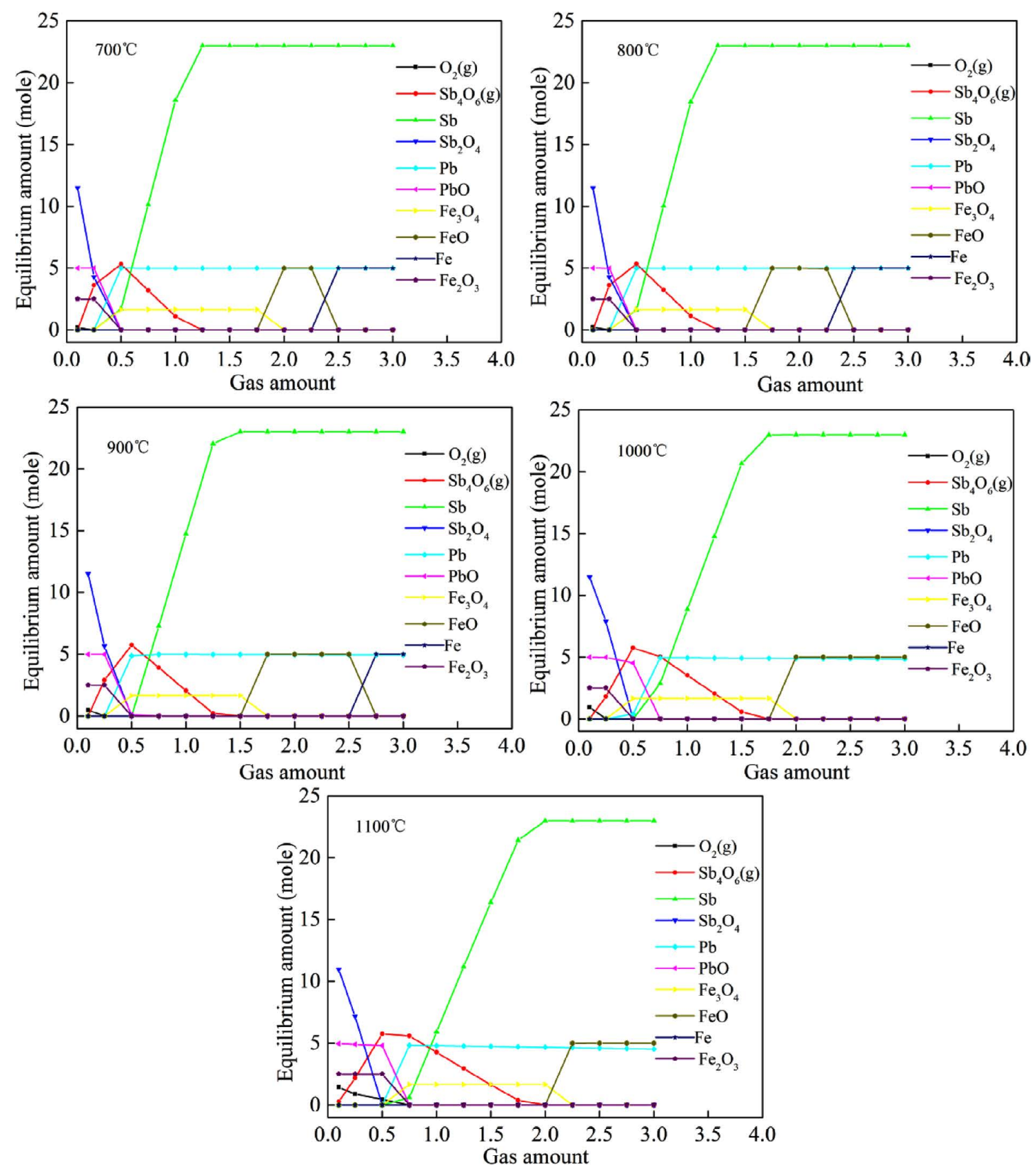

Fig. 5. Equilibrium phases of the Sb-bearing slag roasted with LDPE at different temperatures. (Online version in color.) 


\section{Results and Discussion}

\subsection{Effect of Roasting Temperature}

Under $\mathrm{N}_{2}$ flow rate of $150 \mathrm{ml} / \mathrm{min}$, roasting time of 60 min and LDPE amount of $15.0 \mathrm{wt} \%$, five roasting temperatures of $700^{\circ} \mathrm{C}, 800^{\circ} \mathrm{C}, 900^{\circ} \mathrm{C}, 1000^{\circ} \mathrm{C}$ and $1100^{\circ} \mathrm{C}$ were chosen for studying the effects on the volatilization rate of $\mathrm{Sb}$ and phase transformation of $\mathrm{Pb}$ and $\mathrm{Fe}$. In addition, a contrast experiment using $15.0 \mathrm{wt} \%$ coke with a particle size of 1-3 $\mathrm{mm}$ as reductant was also carried out.

With $15.0 \mathrm{wt} \%$ coke used as reductant, the Sb- and $\mathrm{Pb}-$ containing phases in the original slag are mainly reduced to $\mathrm{Sb}, \mathrm{Pb}$ and $\mathrm{FeSb}_{2}$ as shown in Fig. 6. As a result, the $\alpha$ is small, ranging from $0 \%$ to $13.51 \%$ with temperature from $700^{\circ} \mathrm{C}$ to $1100^{\circ} \mathrm{C}$ and $\beta$ is lower than $1.00 \%$ (Fig. 7). When the LDPE was roasted with the Sb-bearing slag at $700-1100^{\circ} \mathrm{C}$, it would pyrolyze and release $\mathrm{CH}_{4}, \mathrm{H}_{2}$ and $\mathrm{C}_{2}\left(\mathrm{C}_{2} \mathrm{H}_{6}, \mathrm{C}_{2} \mathrm{H}_{4}, \mathrm{C}_{2} \mathrm{H}_{2}\right)$ quickly as reported in Fig. 4. Due to a fast pyrolysis rate of the LDPE at $700-1100^{\circ} \mathrm{C},{ }^{24)}$ some pyrolysis gases had escaped off the roasting system (Fig. $8(B)$ at $900^{\circ} \mathrm{C}$ ) before the reduction reaction with the $\mathrm{Sb}-$ bearing slag, and it causes some $\mathrm{Sb}$ and $\mathrm{Pb}$ phases in the original Sb-bearing slag might only be reduced to $\mathrm{Sb}_{4} \mathrm{O}_{6}$ (g) and $\mathrm{PbO}(\mathrm{g})$ respectively. Correspondingly, $\alpha$ increases from $60.34 \%$ to $83.49 \%$ and $\beta$ increases from $30.17 \%$ to $40.13 \%$ with temperature from $700^{\circ} \mathrm{C}$ to $900^{\circ} \mathrm{C}$ (Fig. 7).

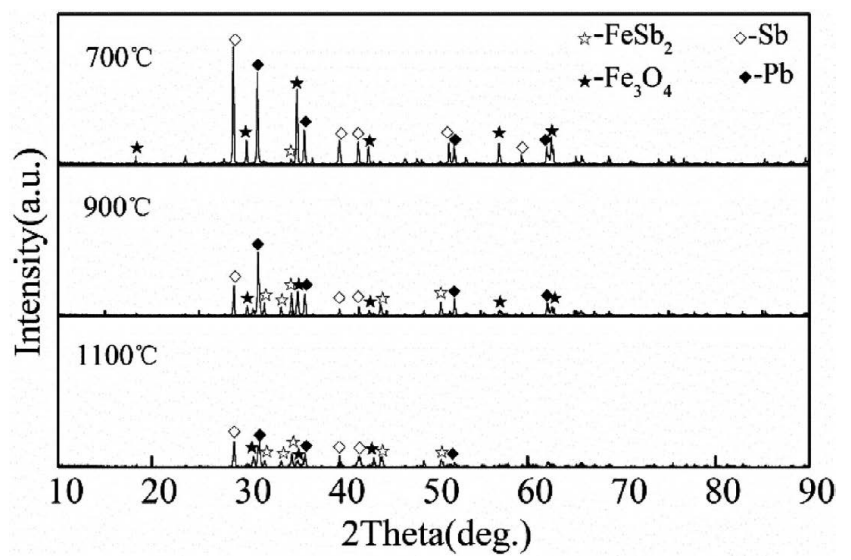

Fig. 6. X-ray diffraction patterns of the roasted residues with 15 $\mathrm{wt} \%$ coke added at different roasting temperatures for 60 $\min$.

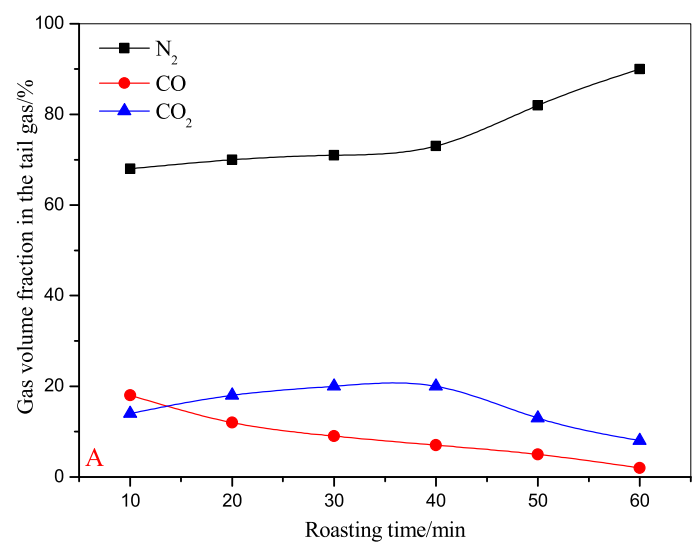

Figure 8 shows the tail gas compositions when the Sb-bearing slag was roasted with $15 \mathrm{wt} \%$ coke and $15 \mathrm{wt} \%$ LDPE respectively. The carrier gas $\mathrm{N}_{2}(150 \mathrm{ml} / \mathrm{min})$ accounts for a lower proportion when the Sb-bearing slag was roasted with LDPE compared to that with coke, and simultaneously volume fractions of $\mathrm{CH}_{4}, \mathrm{H}_{2}$ and $\mathrm{C}_{2}$ in Fig. 8(B) increase from $22 \%$ to $27 \%, 16 \%$ to $19 \%$ and $4 \%$ to $10 \%$ respectively with roasting time from 10 to $30 \mathrm{~min}$. Massive metallic $\mathrm{Pb}$ were generated (Fig. 9) at $1000^{\circ} \mathrm{C}$ and it results the $\mathrm{Pb}$ volatilization rate $(\beta)$ decreases sharply to $1.37 \%$ as shown in Fig. 7. The $\mathrm{Sb}$ was produced with temperature increased to $1100^{\circ} \mathrm{C}$ (Fig. 9), and the $\alpha$ also decreases. In addition, the $\mathrm{Fe}$ mainly exists in form of $\mathrm{Fe}_{3} \mathrm{O}_{4}$ in the roasted residue as shown in Fig. 9, which could be recovered by a general magnetic separation process. The roasting temperature should be fixed at $1000^{\circ} \mathrm{C}$ to improve the separation rate of $\mathrm{Sb}$ from the $\mathrm{Sb}$-bearing slag.

\subsection{Effect of LDPE Addition Amount}

The effect of LDPE amount is studied at temperature of $1000^{\circ} \mathrm{C}$, roasting time of $60 \mathrm{~min}$ and $\mathrm{N}_{2}$ flow rate of 150 $\mathrm{ml} / \mathrm{min}$. With the increase of LDPE amount from $5 \mathrm{wt} \%$ to $25 \mathrm{wt} \%$, the $\mathrm{Pb}_{2} \mathrm{Sb}_{2} \mathrm{O}_{7}$ and $\mathrm{PbSb}_{2} \mathrm{O}_{4}$ amounts decrease and disappear at LDPE dosage of $25 \mathrm{wt} \%$ as shown in Fig. 10. Correspondingly, the $\alpha$ increases from $78.47 \%$ to $93.50 \%$

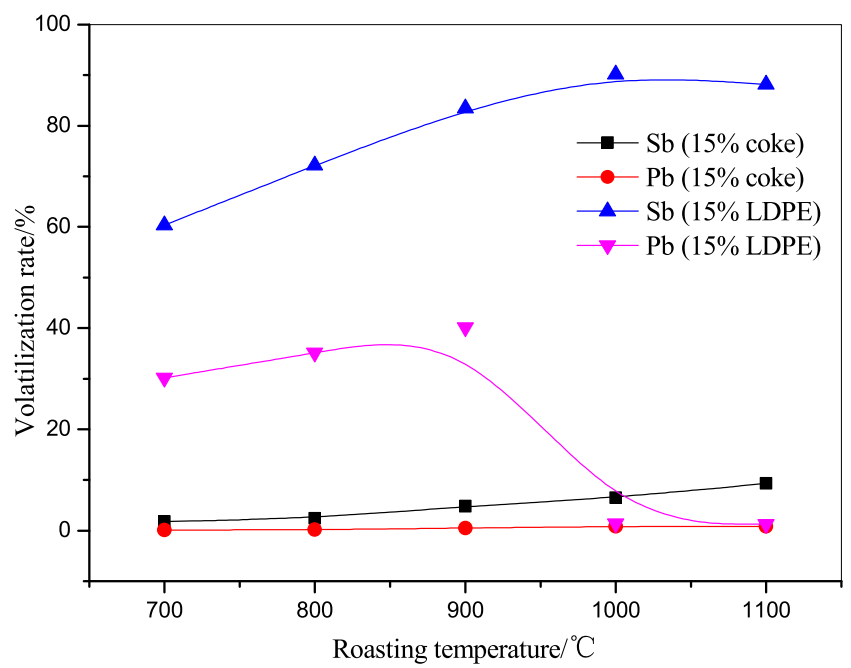

Fig. 7. Effects of roasting temperature on volatilization rates of $\mathrm{Sb}$ and $\mathrm{Pb}$. (Online version in color.)

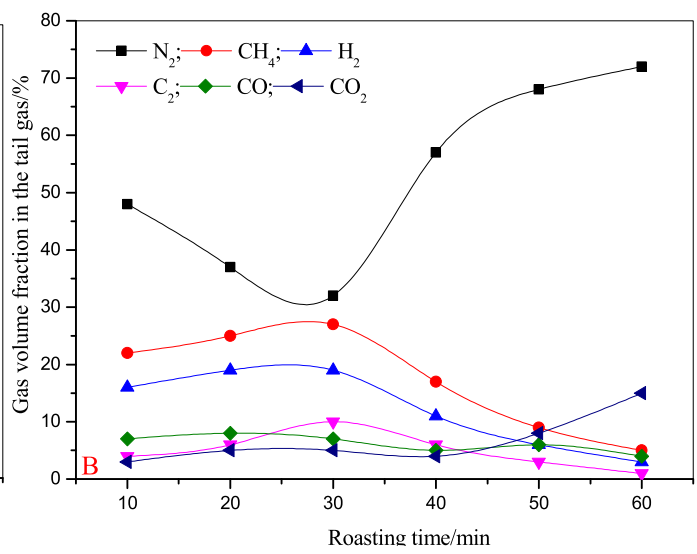

Fig. 8. Compositions of the tail gases with the Sb-bearing slag roasted with $15 \mathrm{wt} \%$ coke (A) and $15 \mathrm{wt} \% \mathrm{LDPE}$ (B) respectively at $900^{\circ} \mathrm{C}$. (Online version in color.) 


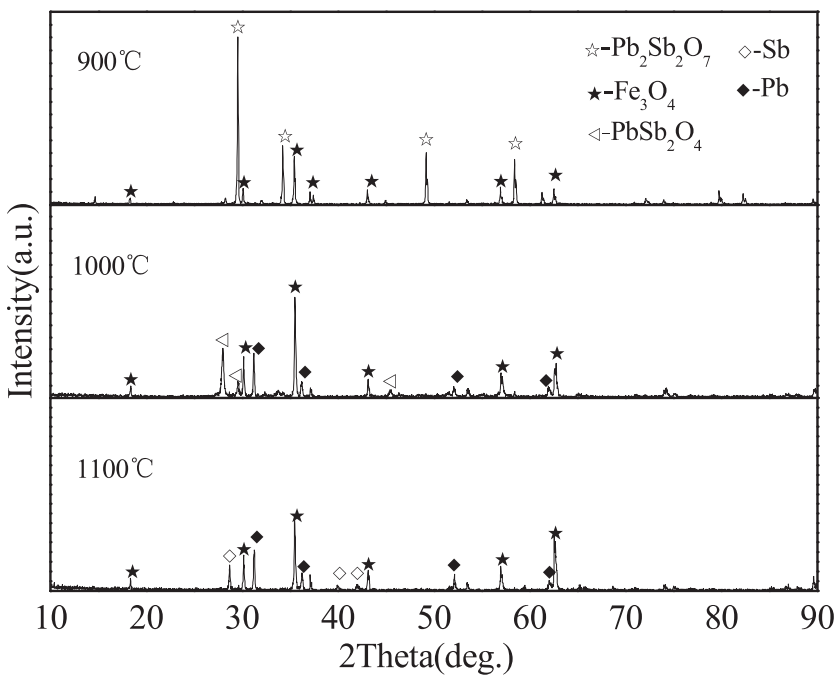

Fig. 9. X-ray diffraction patterns of the roasted residues at different temperatures with $15 \mathrm{wt} \%$ LDPE added for $60 \mathrm{~min}$

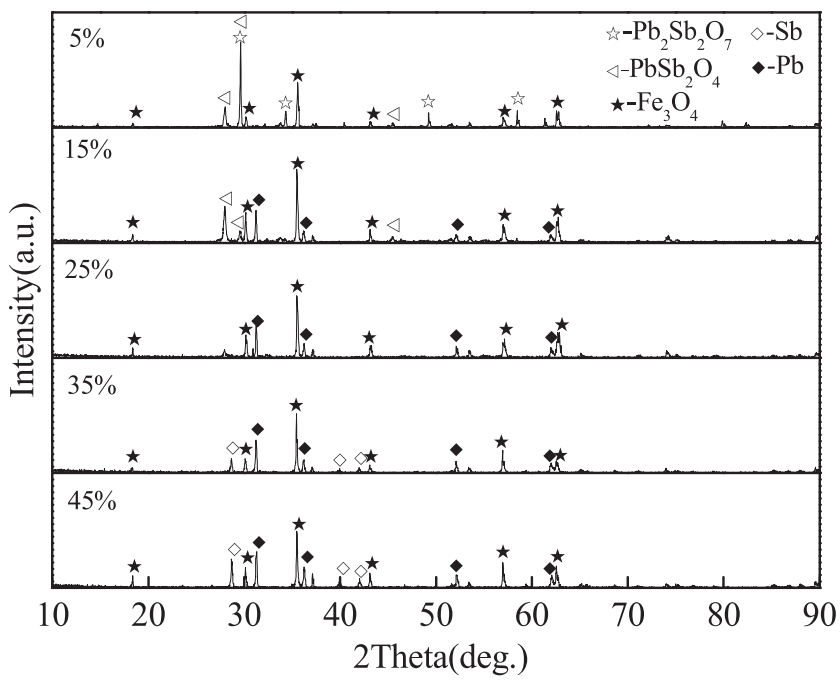

Fig. 10. X-ray diffraction patterns of the roasted residues with different LDPE amounts at $1000^{\circ} \mathrm{C}$ for $60 \mathrm{~min}$.

(Fig. 11) through Eqs. (3) and (4). However, increasing the LDPE dosage to $35 \mathrm{wt} \%$ and $45 \mathrm{wt} \%$ respectively, the metallic $\mathrm{Sb}$ will be formed and increases (Fig. 10), and it causes the $\alpha$ decreases (Fig. 11). More metallic $\mathrm{Pb}$ phases are formed with LDPE dosage from $5 \mathrm{wt} \%$ to $45 \mathrm{wt} \%$ seen from Fig. 10, and it results in the $\beta$ decreasing from $6.43 \%$ to $0.38 \%$ obviously (Fig. 11). For increasing the volatilization rate of $\mathrm{Sb}$, the suitable LDPE amount is $25 \mathrm{wt} \%$.

$$
\begin{aligned}
& \mathrm{Pb}_{2} \mathrm{Sb}_{2} \mathrm{O}_{7}+\mathrm{CH}_{4}, \mathrm{H}_{2} \text { and } \mathrm{C}_{2} \rightarrow \\
& \mathrm{Pb}+\mathrm{Sb}_{4} \mathrm{O}_{6}(\mathrm{~g})+\mathrm{CO}+\mathrm{CO}_{2}+\mathrm{H}_{2} \mathrm{O} \\
& \mathrm{PbSb}_{2} \mathrm{O}_{7}+\mathrm{CH}_{4}, \mathrm{H}_{2} \text { and } \mathrm{C}_{2} \rightarrow \\
& \mathrm{Pb}+\mathrm{Sb}_{4} \mathrm{O}_{6}(\mathrm{~g})+\mathrm{CO}+\mathrm{CO}_{2}+\mathrm{H}_{2} \mathrm{O}
\end{aligned}
$$

\subsection{Effect of Roasting Time}

Figure 12 shows that the $\mathrm{PbSb}_{2} \mathrm{O}_{4}$ amount in roasted residues decreases and metallic $\mathrm{Pb}$ amount increases with roasting time, and the $\mathrm{PbSb}_{2} \mathrm{O}_{4}$ disappears at roasting time of 60

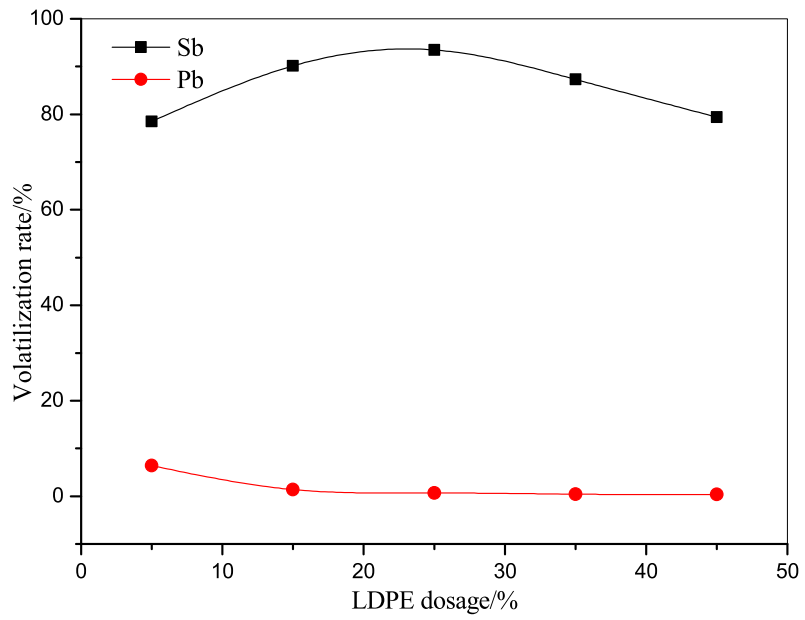

Fig. 11. Effects of LDPE amount on volatilization rates of $\mathrm{Sb}$ and $\mathrm{Pb}$ at $1000^{\circ} \mathrm{C}$ for $60 \mathrm{~min}$. (Online version in color.)

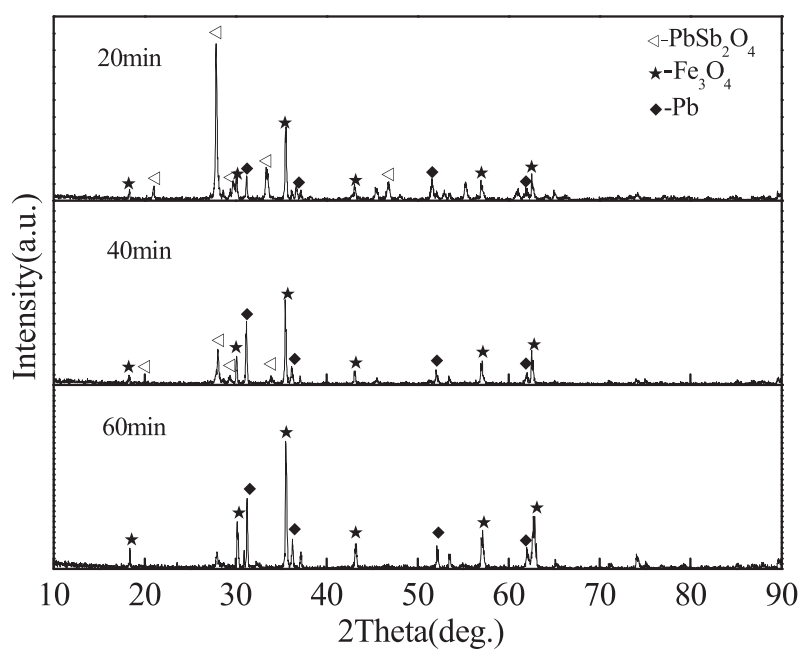

Fig. 12. X-ray diffraction patterns of roasted residues at $1000^{\circ} \mathrm{C}$ with $25 \mathrm{wt} \%$ LDPE for different roasting time.

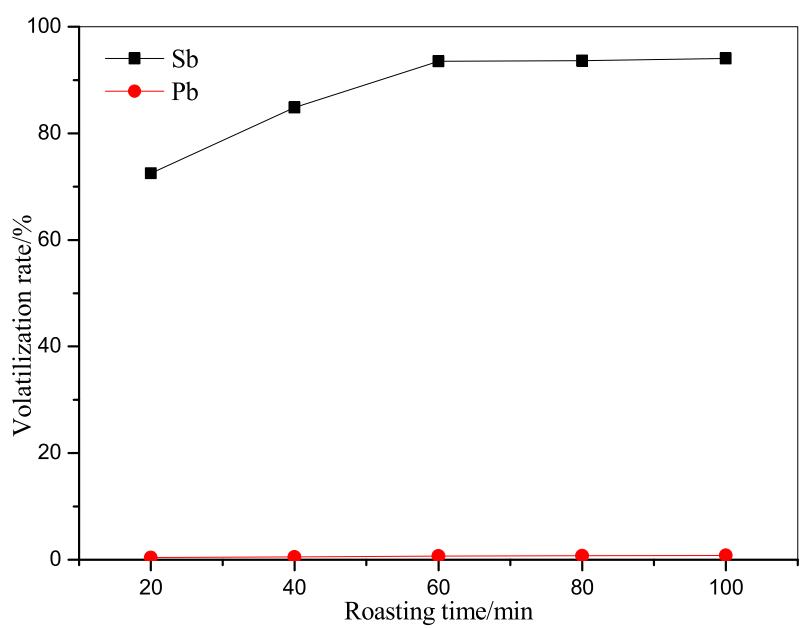

Fig. 13. Effects of roasting time on volatilization rates of $\mathrm{Sb}$ and $\mathrm{Pb}$ at $1000^{\circ} \mathrm{C}$ with $25 \mathrm{wt} \%$ LDPE added. (Online version in color.)

min. Correspondingly, the $\alpha$ reaches a maximum of $93.51 \%$ at this roasting time and then becomes almost constant with roasting time increase (Fig. 13). The $\beta$ is lower than $1 \%$ and 

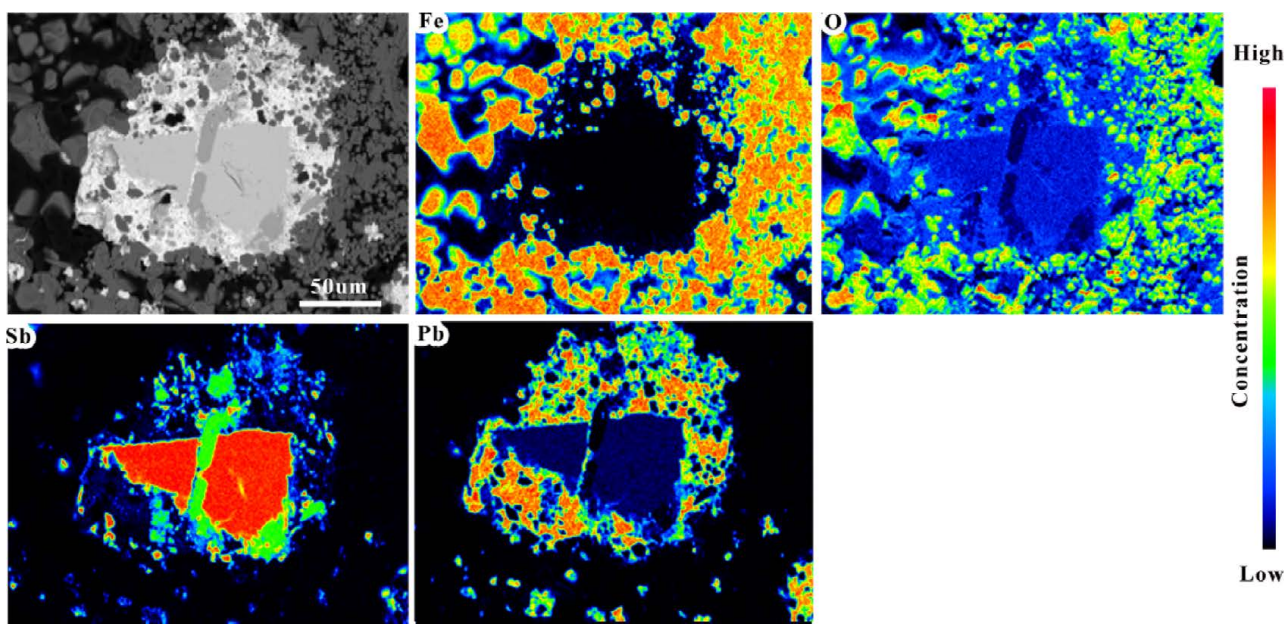

Fig. 14. Element distribution of the roasted residue obtained by EPMA. (Online version in color.)

remains nearly constant with roasting time changing (Fig. 13). Considering $\alpha$ and $\beta$, it is concluded that $60 \mathrm{~min}$ is an appropriate roasting time.

For increasing the $\mathrm{Sb}$ separation rate from the Sb-bearing slag, this roasting process with LDPE should be carried out at a roasting temperature of $1000^{\circ} \mathrm{C}$, LDPE dosage of 25 $\mathrm{wt} \%$, and roasting time of $60 \mathrm{~min}$. Under these optimum conditions, the volatilization rate of $\mathrm{Sb}$ is approximately $93.51 \%$ and that of $\mathrm{Pb}$ is only around $0.68 \%$ (Fig. 13), and meanwhile the $\mathrm{Fe}$ component in the slag is almost transformed into $\mathrm{Fe}_{3} \mathrm{O}_{4}$ (Fig. 12). Figure 14 shows that most $\mathrm{Fe}_{3} \mathrm{O}_{4}$ in the roasted residue are distributed independently from $\mathrm{Pb}$ phases. This $\mathrm{Fe}_{3} \mathrm{O}_{4}$ can be separated and recovered from the roasted residues using magnetic separation process, thereby rendering $\mathrm{Fe}$ and $\mathrm{Pb}$ in the $\mathrm{Sb}$-bearing slag resource utilization.

\section{Conclusions}

The effective separation of $\mathrm{Sb}$ from Sb-bearing slag through a reduction roasting process using LDPE was feasible. The factors of roasting temperature, LDPE addition amount and roasting time played significant roles.

During the LDPE pyrolysis process, the $\mathrm{C}_{2}\left(\mathrm{C}_{2} \mathrm{H}_{6}, \mathrm{C}_{2} \mathrm{H}_{4}\right.$, $\left.\mathrm{C}_{2} \mathrm{H}_{2}\right)$ mole fraction decreases while the $\mathrm{C}_{1}\left(\mathrm{CH}_{4}\right)$ and $\mathrm{H}_{2}$ mole fractions increase with temperature. The $\mathrm{Sb}$ can be separated from the $\mathrm{Sb}$-bearing slag in the form of $\mathrm{Sb}_{4} \mathrm{O}_{6}(\mathrm{~g})$ at temperature of $900^{\circ} \mathrm{C}$ and LDPE pyrolysis gas amount of 0.5 from the point of view of thermodynamics. Some pyrolysis gas of LDPE will escape off the roasting system before the reaction with the Sb-bearing slag, and this results some $\mathrm{Sb}$ and $\mathrm{Pb}$ phases in the original $\mathrm{Sb}$-bearing slag might only be reduced to $\mathrm{Sb}_{4} \mathrm{O}_{6}(\mathrm{~g})$ and $\mathrm{PbO}(\mathrm{g})$ respectively. Volatilization rate of $\mathrm{Sb}$ could be increased obviously with a certain LDPE addition. At roasting temperature of $1000^{\circ} \mathrm{C}$, LDPE dosage of $25 \mathrm{wt} \%$ and roasting time of $60 \mathrm{~min}$, the volatilization rate of $\mathrm{Sb}$ is approximately $93.51 \%$ and that of $\mathrm{Pb}$ is only around $0.68 \%$, and meanwhile the $\mathrm{Fe}$ component is almost transformed to $\mathrm{Fe}_{3} \mathrm{O}_{4}$. This $\mathrm{Fe}_{3} \mathrm{O}_{4}$ can be separated and collected from the roasted residues using magnetic separation process. ${ }^{27,28)}$

\section{Acknowledgments}

The authors wish to express thanks to National Science Fund for Distinguished Regional Scholars (51564034) and National Key R\&D Program of China (2017YFC0210501) for financial support of this research.

\section{REFERENCES}

1) S. M. Mostasshari and S. Baie: J. Therm. Anal. Calorim., 94 (2008), 97.

2) G. Strbac, D. Strbac, S. Lukic-Petrovic and M. Siljegovic: J. Therm. Anal. Calorim., 127 (2017), 247.

3) A. Beutl, D. Henriques, V. Motalov, D. Cupid, T. Markus and H. Flandorfer: J. Therm. Anal. Calorim., 131 (2018), 2673.

4) D. P. Zhong, L. Li and C. Tan: J. Cent. South Univ., 25 (2018), 1904.

5) C. Tan, L. Li, K. Z. Li and D. P. Zhong: Sep. Purif. Technol., 194 (2018), 81.

6) L. Li, F. Y. Wang, D. P. Zhong, C. Tan and Y. Yu: ISIJ Int., 57 (2017), 581.

7) X. Y. Guo, J. Shi, Y. Yi, Q. H. Tian and D. Li: J. Environ. Chem. Eng., 3 (2015), 2236.

8) X. Zhang, Z. H. Liu, Y. H. Li, Z. Y. Liu and Q. H. Li: J. Cent. South Univ., 45 (2014), 1390.

9) W. Y. Wan, W. Chen, S. H. Huang and X. P. Peng: Chin. J. Nonferrous Met., 44 (2015), 32 (in Chinese).

10) X. Hu, S. L. Wang, T. Lei and X. Wu: Min. Metall., 23 (2014), 36 (in Chinese)

11) D. P. Zhong, L. Li and C. Tan: Metall. Mater. Trans. B, 48 (2017), 1308.

12) B. B. Fu and K. Q. Qiu: Vacuum, 149 (2018), 319.

13) J. Z. Chen, H. Z. Cao, B. Li, H. J. Yuan, G. Q. Zheng and T. Z. Yang: Trans. Nonferrous Met. Soc. China, 19 (2009), 730.

14) K. Q. Qiu and R. L. Zhang: Vacuum, 80 (2006), 1016.

15) R. L. Zhang, X. F. Zhang, S. Z. Tang and A. D. Huang: Ultrason. Sonochem., 27 (2015), 187.

16) Y. B. Zhao, X. D. Lv and H. G. Ni: Chemosphere, 209 (2018), 707.

17) A. K. Panda, R. K. Singh and D. K. Mishra: Renew. Sustain. Energy Rev., 14 (2010), 233.

18) P. A. Bozkurt, O. Tosun and M. Canel: J. Energy Inst., 90 (2017), 355.

19) Y. Barba-Gutierrez, B. Adenso-diaz and M. Hopp: Resour. Conserv. Recycl., 52 (2008), 481.

20) K. Hamad, M. Kaseem and F. Deri: Polym. Degrad. Stab., 98 (2013), 2801.

21) R. X. Wang and Z. M. Xu: Waste Manage., 34 (2014), 1455.

22) J. Aguado, D. P. Serrano and J. M. Escola: Ind. Eng. Chem. Res., 47 (2008), 7982.

23) J. C. Acomb, C. F. Wu and P. T. Willianms: Appl. Catal. B-Environ., 147 (2014), 571.

24) P. T. Williams and E. A. Williams: J. Anal. Appl. Pyrolysis, 51 (1999), 107.

25) G. X. Yan, X. D. Jing, H. Wen and S. G. Xiang: Energ. Fuel., 29 (2015), 2289.

26) J. M. Berthelot and Y. Sefrani: Compos. Sci. Technol., 64 (2004), 1261.

27) H. Kubo, K. M. Yokoyama and T. Nagasaka: ISIJ Int., 50 (2010), 59.

28) W. Yu, T. C. Sun and T. Y. Hu: ISIJ Int., 55 (2015), 329. 